\title{
Offices of Research Facilities Development and Operations
}

National Cancer Institute

\section{Source}

National Cancer Institute. Offices of Research Facilities Development and Operations.

NCI Thesaurus. Code C82628.

An office within the National Institutes of Health that supports the organization's mission by providing, maintaining, and operating safe, healthy, and attractive facilities. 